\title{
Botanical and genetic characterization of Hibiscus syriacus L. cultivated in Egypt
}

\author{
Jailan M. N. El Shazly ${ }^{1 *}$, Sabah H. El Gayed ${ }^{1}$, Zeinab A. Kandili1, Nemat A. Yassin², Sahar A. Tawab ${ }^{3}$, Taha S. M. ElAlfy ${ }^{1}$ \\ ${ }^{1}$ Department of Pharmacognosy, Faculty of Pharmacy, Cairo University, Giza, Egypt. \\ ${ }^{2}$ Department of Pharmacology, National Research Center, Cairo, Egypt. \\ ${ }^{3}$ Department of Botany, Faculty of Women, Ain Shams University, Cairo, Egypt.
}

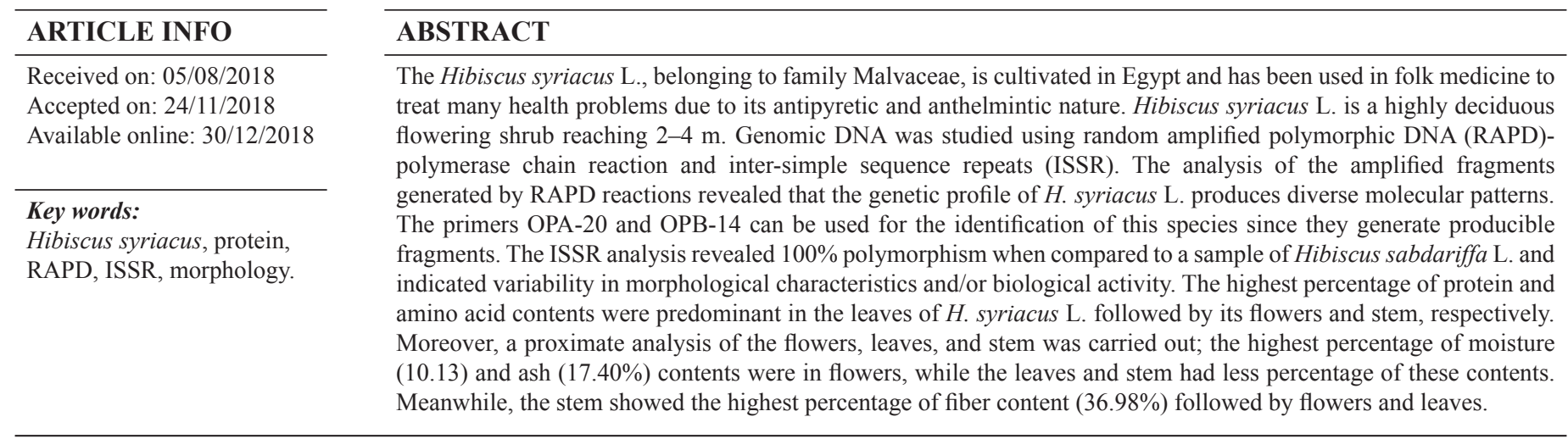

\section{INTRODUCTION}

Family Malvaceae belongs to the order of Malvales, which is a family of dicotyledonous flowering plants. It contains about 244 genera with around 4,225 known species (Christenhusz and Byng, 2016). Malvaceae plants are distributed worldwide and are characterized by stellate simple uni-cellular hairs. Mucilage cells are very common in the parenchyma (Metcalfe and Chalk, 1950).

Hibiscus plants are herbaceous, either annual or perennial, and characterized by the presence of stellate and/or simple unicellular hairs. They are famous for their lobed, alternate petiolate leaves with an obtuse truncated base; their flowers are axillary and solitary (Welsh, 1980).

\footnotetext{
"Corresponding Author

Jailan M. N. El Shazly, Department of Pharmacognosy, Faculty of

Pharmacy, Cairo University, Giza, Egypt.

E-mail: jailan.mn.elshazly@std.pharma.cu.edu.eg
}

Hibiscus syriacus L. is a deciduous flowering shrub called Rose of Sharon belonging to the Malvaceae family. Its name indicates that it was first identified in Syria but most likely originated in Korea and Southern China (Huxley, 1992). Currently, it is widely cultivated in North America and Eastern Asia (Maganha et al., 2010; Welsh, 1980). Hibiscus syriacus L. is found in the wild on mountain slopes, sunny edges of gardens, hedges, and partly in shaded gardens. It has also been found in various gardens of Egypt (Huxley, 1992).

The dried flower of $H$. syriacus $\mathrm{L}$. is used commercially as a tea in Europe. The water-soluble mucilages extracted from the leaves of $H$. syriacus L. exhibit hypoglycemic activity (Perez et al., 1998). However, water extract of the leaves has anti-mycobacterial activity (Gautam et al., 2007). The root bark of H. syriacus L. was used in folk medicine as an antipyretic, anthelmintic, fungicide, and as a treatment of hematochezia (Maganha et al., 2010; Yun et al., 2001). Meanwhile, its root bark exhibits antioxidant and significant cytotoxic activities (Yun et al., 2001).

Investigation of the genetic diversity of the studied plant's genomic DNA, using various molecular markers, has a great 
importance for the genetic characterization of medicinal plants (Sundaram and Purwar, 2011). Random amplified polymorphic DNA (RAPD) and inter-simple sequence repeats (ISSR) are two of the most popular markers based on a polymerase chain reaction (PCR). Such markers have been extensively used in the study of the genetic variability of various medicinal plants (Tripathi et al., 2012). RAPD markers involve many loci and cover a large part of the genome. They also provide more valuable information into population differentiation (Ince et al., 2010). ISSR-PCR is a technique which involves the use of microsatellite sequences as a primer to generate multi-locus markers. ISSR markers are highly polymorphic and are useful in studying genetic diversity and phylogeny (Reddy et al., 2002).

The aim of this study is to characterize $H$. syriacus L., macro- and micro-morphological characters of the stem, leaves, and flowers to find its diagnostic features and pinpoint these identifications, in both the entire plant and its powder. Proximate analyses are being carried out to assist in the detection of the quality, purity, and uniformity of the plant for quality control. Amino acids analysis is the primary step to characterize the protein structure. Molecular or generic characteristics of $H$. syriacus L., cultivated in Egypt, were carried out by protein fingerprint and DNA fingerprint:

\section{a- RAPD-PCR \\ b- ISSR-PCR}

(ISSR was the method used to compare between $H$. syriacus L. and H. Sabdariffa L., where H. Sabdariffa L. was used as a standard.)

\section{MATERIALS AND METHODS}

\section{Plant material}

Sample leaves, flowers, and stems of $H$. syriacus L. were collected in June from a private garden in El Monofia governorate, Egypt. The plant identity was authenticated by Dr. Wafaa Amer, Head of the Botany and Microbiology Department, Faculty of Science, Cairo University. A specimen with a voucher was (No. 16-7-2018) deposed at the Herbarium of the Pharmacognosy Department, Faculty of Pharmacy, Cairo University.

\section{Genetic study}

\section{DNA fingerprint}

RAPD: DNA-PCR amplification was carried out in a programmed thermocycler (PTC-100), $95^{\circ} \mathrm{C}$ for 5 minutes (one cycle), followed by $94^{\circ} \mathrm{C}$ for 1 minute, $36^{\circ} \mathrm{C}$ for 1 minute, and $72^{\circ} \mathrm{C}$ for 2 minutes ( 45 cycle), with an extension at $72^{\circ} \mathrm{C}$ for 5 minutes (one cycle). Twelve RAPD primers with sequence (5'-3') were applied to determine the DNA fingerprint: OPB-01, OPB-14, OPC-05, OPC-02, OPA-13, OPA-20, OPA-04, OPO-09, OPO-02, OPE-05, OPG-10, and OPH-02. The amplification products were separated by electrophoresis in a $1.5 \%$ agarose gel containing ethidium bromide $(0.5 \mu \mathrm{g} / \mathrm{ml})$ in a $1 \times$ TAE $(40 \mathrm{mM}$ Tris-Acetic, $1 \mathrm{mM}$ EDTA) buffer at $95 \mathrm{~V}$. PCR products were visualized by UV light, photographed using a Polaroid camera, and analyzed by a gel documentation system (GeneSnap software by Syngene). Banding patterns generated by RAPD-PCR were classified by size and compared using standard DNA markers to determine the genetic fingerprint.
ISSR: ISSR-PCR reactions were conducted according to Zietkiewicz et al. (1994). For the genotypes analysis, twelve selective ISSR primers were used. Only five succeeded: HB11(GT)6CC; HB10(GA)6CC; HB8(GA)6GG; HB13(GAG)3GC; 17899A(CA)6AG (Macrogen Inc., Seoul, Korea). DNA amplification was programmed for denaturation (one cycle) at $94^{\circ} \mathrm{C}$ for 2 minutes, followed by 30 cycles, $94^{\circ} \mathrm{C}$ for 30 seconds, $33^{\circ} \mathrm{C}-50^{\circ} \mathrm{C}$ for 45 seconds, $72^{\circ} \mathrm{C}$ for 1 minute, and finally, one cycle extension at $72^{\circ} \mathrm{C}$ for 20 minutes and $4^{\circ} \mathrm{C}$ (infinitive). The amplification products were resolved in $1.5 \%$ agarose gel in $1 \times$ TAE buffer. The gel was run at $120 \mathrm{~V}$ for about 1 hour and was photographed and scanned using a gel documentation system (GeneSnap software by Syngene).

Protein profile: A protein pattern was detected with sodium dodecyl sulfate-polyacrylamide gel electrophoresis (SDS-PAGE) of $12.5 \%$ using a broad range unstained protein ladder (Thermo Fisher Scientific Inc, Rockford, IL) with a 0.75 mm thickness according to Laemmli (1970); Wilson and Jones (1983). A weight of $1 \mathrm{~g}$ of flower buds was powdered using liquid nitrogen, extracted with $1 \mathrm{ml}$ of extraction buffer (1.21 g Tris$\mathrm{HCl}, 1 \mathrm{ml} \mathrm{10 \%}$ SDS, $0.5 \mathrm{ml} \beta$-mercaptoethanol, and $5 \mathrm{~g}$ sucrose

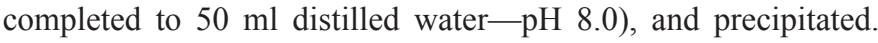
Then the pellets were dissolved with a sample buffer (1.2 $\mathrm{ml}$ Tris-

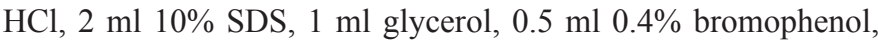
$0.5 \mathrm{ml} \beta$-mercaptoethanol, and $4.8 \mathrm{ml}$ distilled water) following the protocol of Gallagher (2012). The homogenate was boiled in a water bath for 90 seconds, loaded on the gel, and allowed to run at $70 \mathrm{~V}, 40 \mathrm{ma}$. Finally, the gel was stained with a Coomassie Brilliant Blue (R 2) stain and destained following the protocol of Gallagher (2012). The gel was photographed and scanned for analysis using a gel documentation system software (GeneSnap software by Syngene). Protein bands were identified by comparing their molecular weights with those of a medium range marker.

\section{Determination of protein and amino acid contents}

\section{Determination of protein}

Total proteins were determined spectrophotometrically using Kjeldahl's method according to AOAC (2000).

\section{Determination of amino acids}

First, amino acids were subjected to acid hydrolysis, then were determined spectrophotometrically using an Automatic Amino Acid Analyzer (AAA 400, INGOS Ltd) according to Block et al. (1958).

\section{Morphological and anatomical studies}

Samples of the stems, leaves, and flowers were first separated, where each organ was freshly examined after being kept in 5\% glycerol added to $70 \%$ ethanol. Each organ was finely powdered after being dried in shade. The morphological features were photographed using a Sony Xperia Z3 phone during the month of June with a 20.7-megapixel, $25 \mathrm{~mm}$ G Lens optics (f 2.0), boasting up to 12,800 ISO sensitivity in daylight, with low ISO and high shutter speed, and examined by a bare-eye. A ruler $(\mathrm{cm})$ has been used for the measurement of some samples. Histological samples in which sections in the leaf, petiole, stem, and the ovary of the flower were prepared by free-hand, according to the method adopted by Kraus and Arduin (1997). Later, histological sections 
were examined using Leica DMLB, a light microscope image analyzer connected to Leica JVC digital 0.5 " CCD camera.

\section{Proximate analysis}

\section{Determination of moisture, ash, and crude fiber contents}

Proximate analyses have been applied on the fine powder of the air-dried leaves, stem, and flower of $H$. syriacus L. in shade, according to the procedures of the Association of Official Analytical Chemistry (AOAC, 2000).

\section{RESULTS AND DISCUSSION}

\section{Morphological investigation of Hibiscus syriacus $\mathbf{L}$.}

Hibiscus syriacus L. (Fig. 1) is a wild annual hardy deciduous shrub. It is upright and vase-shaped, reaching $2-4 \mathrm{~m}$ in height. It usually flowers from June to October.

\section{The stem}

The stem (Fig. 2) is woody, cylindrical, and monopodial. The terminal bud grows centrally to a leader shoot and the lateral branches are subordinate and pale gray in color. It is odorless with a slight mucilaginous taste. The main stem bears both flowering and foliage alternate branches, termed a multi-stem

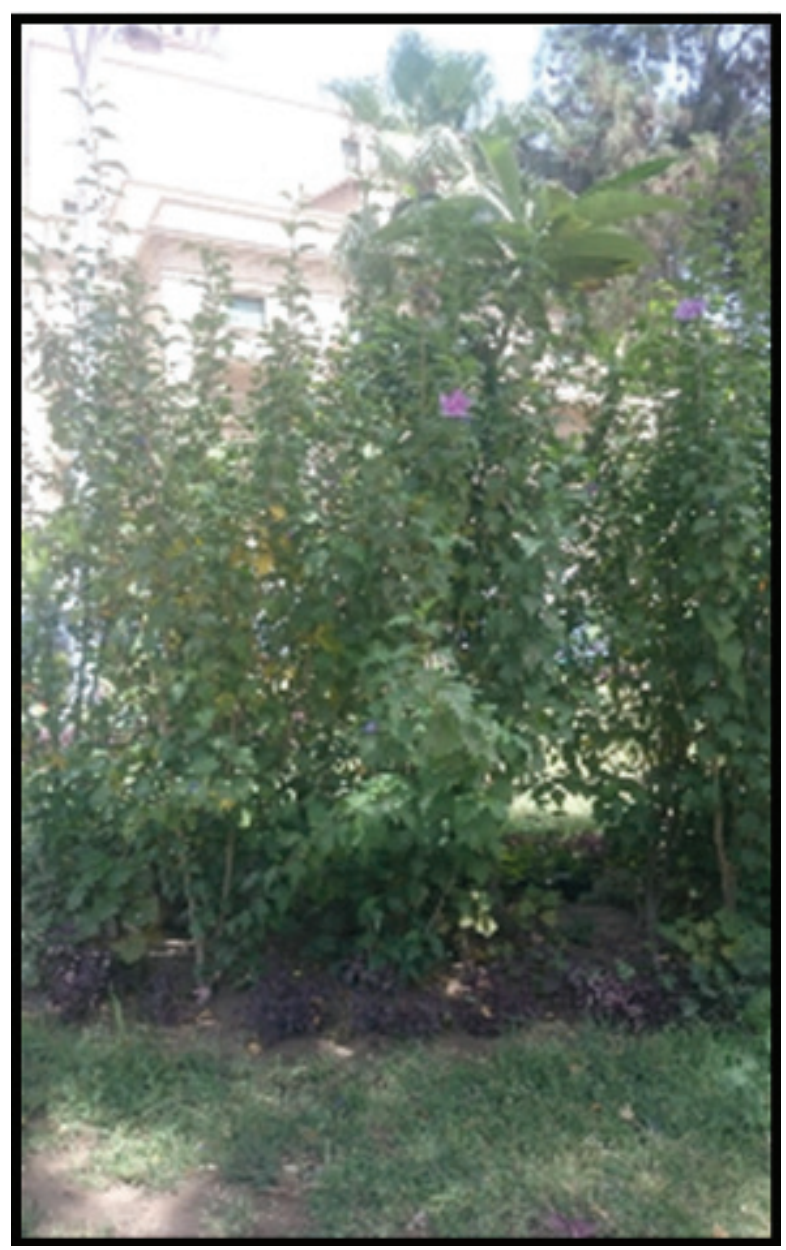

Figure 1. A photograph of $H$. syriacus L. Shrubs. $X=0.03$. trunk. The internodes measure $2-6 \mathrm{~cm}$ in length, being shorter near the apex. The stem measures $60-650 \mathrm{~cm}$ in height and $3.5-$ $6 \mathrm{~cm}$ in diameter.

\section{The leaves}

The leaves (Fig. 3) are simply lobed with a rough serrated edge with a triangular-ovate form. They are also alternate in arrangement, cauline, petiolate, and stipulate. Lamina is a simple, ovoid-rhomboidal in shape having a sub-acute apex, a cuneate base that is green in color and the upper surface is darker than the lower surface. They are dark green in summer while yellow in the fall. They measure $2-8.5 \mathrm{~cm}$ long and $2-4.7 \mathrm{~cm}$ wide. The venation is pinnately reticulate and the midrib and big veins are prominent on the lower surface. The petiole is dark green in color, adaxial in pubescence, stellate, and cylindrical. They measure $1-2.7 \mathrm{~cm}$ in length.

\section{The flowers}

The flowers are hermaphrodite, actinomorphic, and an array in a cyme. The colored calyx consists of five purple to blue lavender chiffon petals with crimson bases. It is a solitary, pedicel, terminal, or in the axils of the upper leaves. They measure 5.5-7 $\mathrm{cm}$ in length and 2.5-4 cm in diameter. The floral formula is $\oplus$, ơ $K(5), C(5), \mathrm{A} \infty$, and $G / G(5)$.

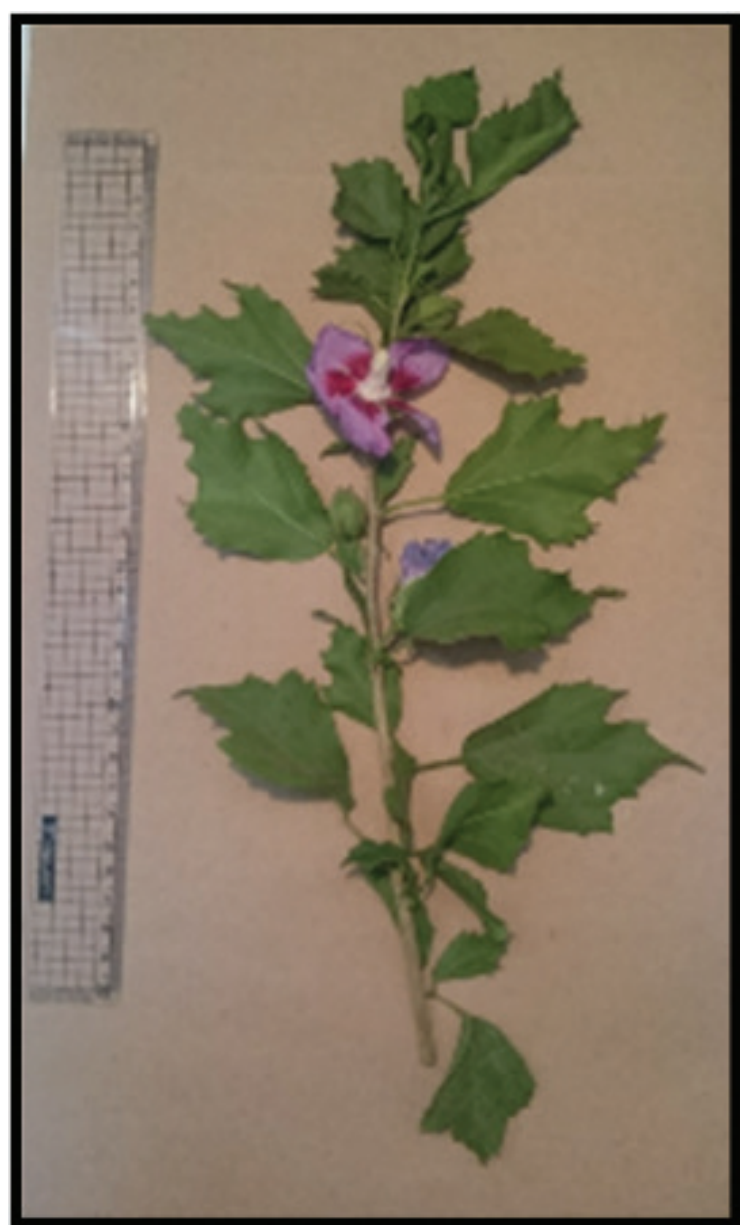

Figure 2. A photograph of $H$. syriacus $\mathrm{L}$. branch showing the flower, leaves, and stem. $X=0.2$ 


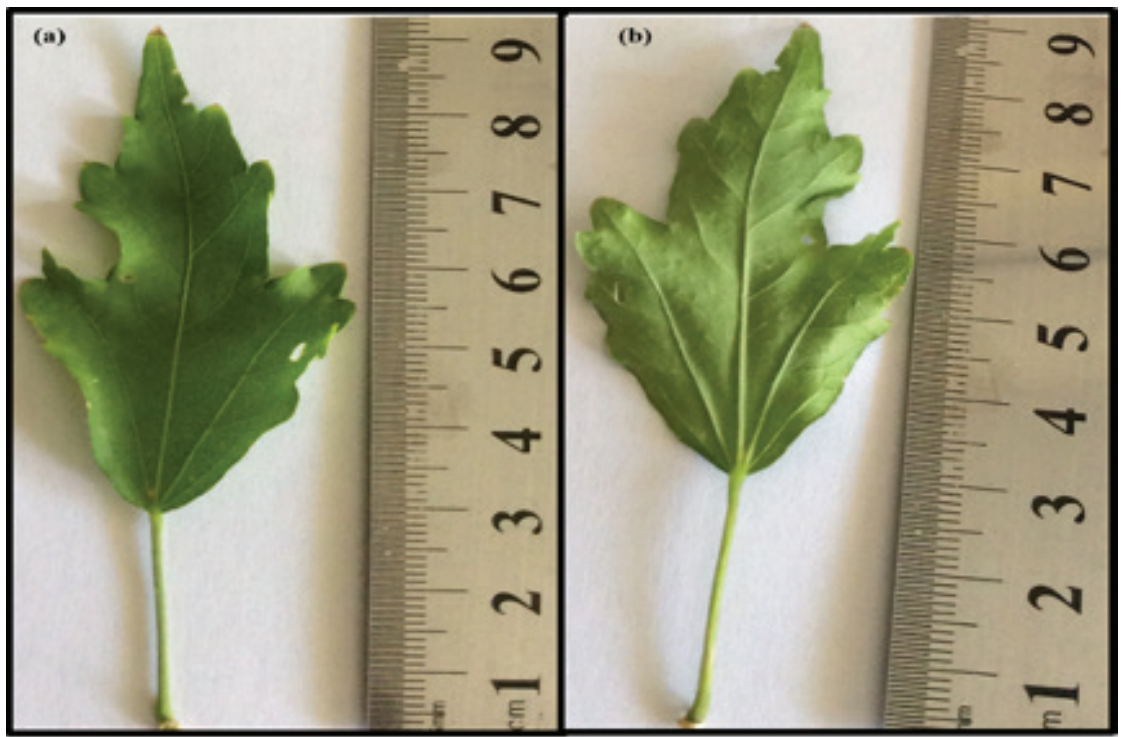

Figure 3. Photographs of the leaves of $H$. syriacus L. (a): upper surface. $X=0.6$; (b): lower surface. $X=0.7$.

The pedicle of the flower is cylindrical and green in color. It measures $1.5-2 \mathrm{~cm}$ in length and $0.3-0.5 \mathrm{~cm}$ in diameter. The epicalyx (Fig. 4) is formed of five linear-lanceolate green bracts stellate in shape, free, and connate at the base outside the calyx. The branches are green in color, hairy, and measure 1-1.3 $\mathrm{cm}$ in length and $0.1-0.2 \mathrm{~cm}$ in diameter. The calyx (Fig. 4) is campanulate in shape and formed of five united sepals showing valvate aestivation. The sepals are green in color. Each sepal contained three nerves and was fleshy with a hairy outer surface measuring $1.2-2 \mathrm{~cm}$ in length and $0.7-1 \mathrm{~cm}$ in diameter. The corolla (Fig. 5) is a funnel form, consisting of five free, obovate petals. They are purple on the first day turning to blue lavender in color on the second day with crimson spots at the base of the ventral surface. The petals measured $4-6 \mathrm{~cm}$ in length and $2.5-5$ $\mathrm{cm}$ in width. The flower is bisexual. It is formed of reproductive organs, androecium and gynoecium. Androecium is formed of fine petaloid stamens and hardly observed. The gynoecium was petaloid club-shaped, made up of a pistil, stigmas, and an urnshaped ovary.

\section{Anatomical features of Hibiscus syriacus $\mathrm{L}$.}

The stem

A circular transverse section was taken from a branch in the stem of $H$. syriacus L. and the following should be noted: (Fig. 6).

The epidermis consisted of polygonal axially elongated cells with straight anticlinal walls, devoid of stomata. The hypodermis was elongated and the epidermal cells were divided transversally. Cork was formed in three to four rows radially arranged in dark brown tabular polygonal, tangentially elongated cells with thick lignified walls. The phelloderm or secondary
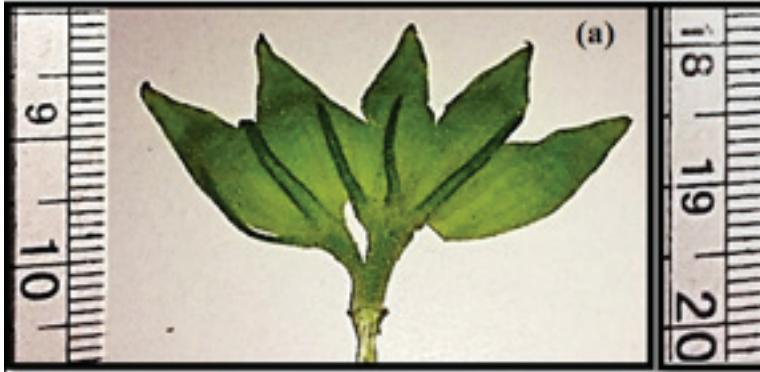

(b)
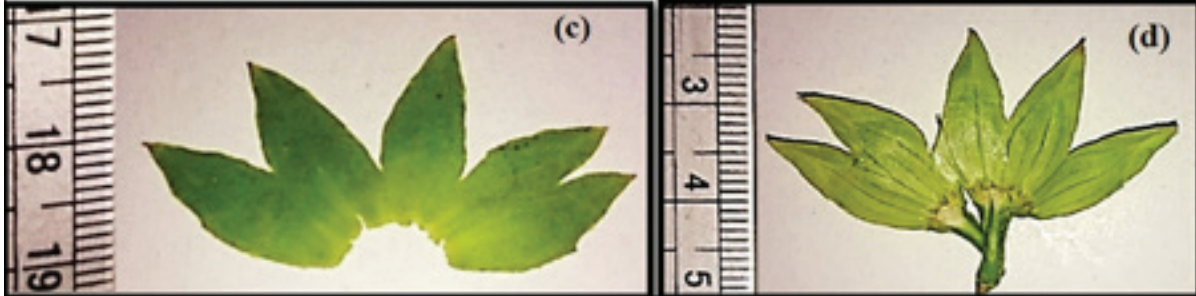

Figure 4. Photographs of the calyx and the epicalyx of H. syriacus L. (a): The epicalyx and calyx attached together. $X=0.9$; (b): The epicalyx. $X=1$; (c): The calyx upper surface. $X=0.9 ;(\mathrm{d})$ : The calyx lower surface. $X=0.6$. 


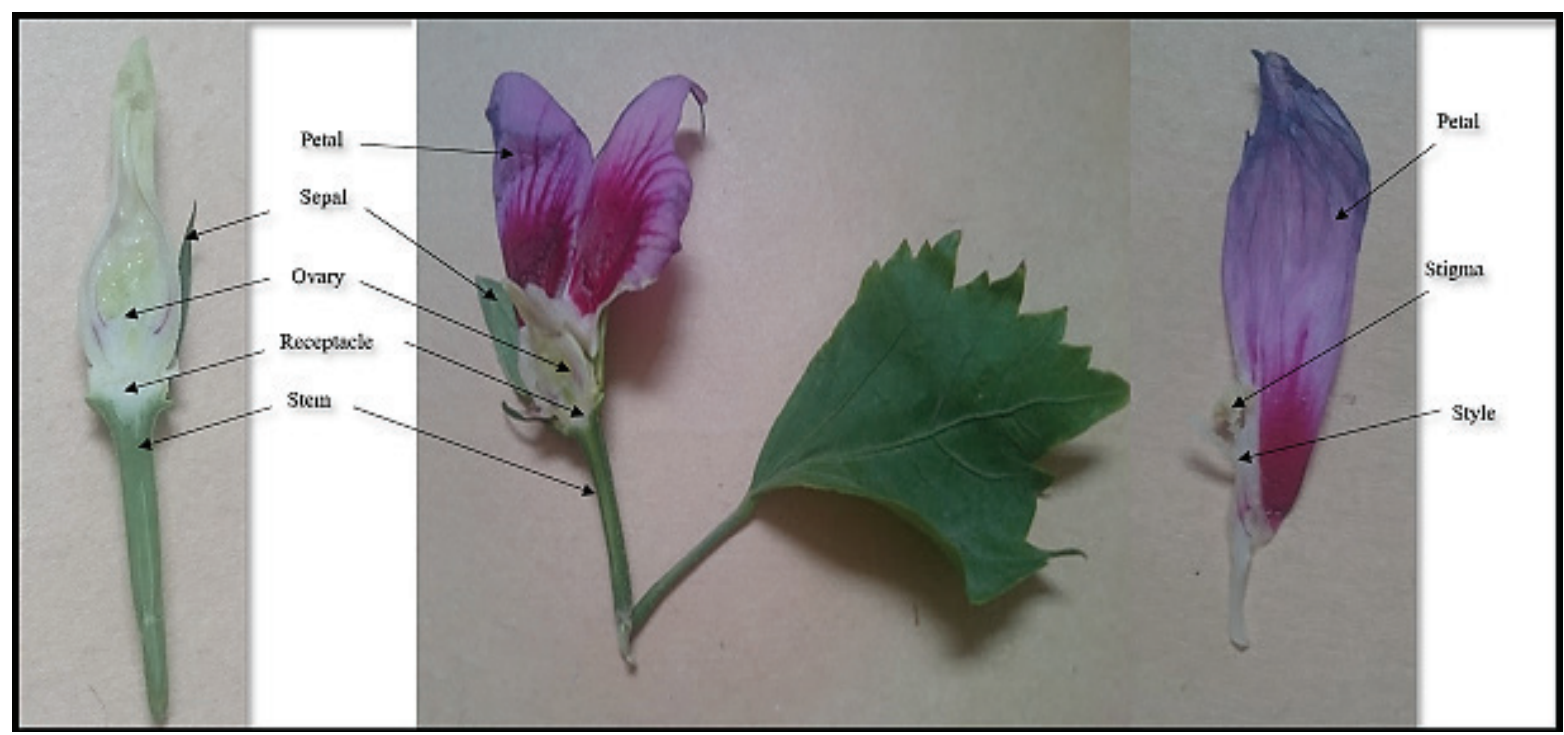

Figure 5. Photographs of LS in the H. syriacus L. Flower.

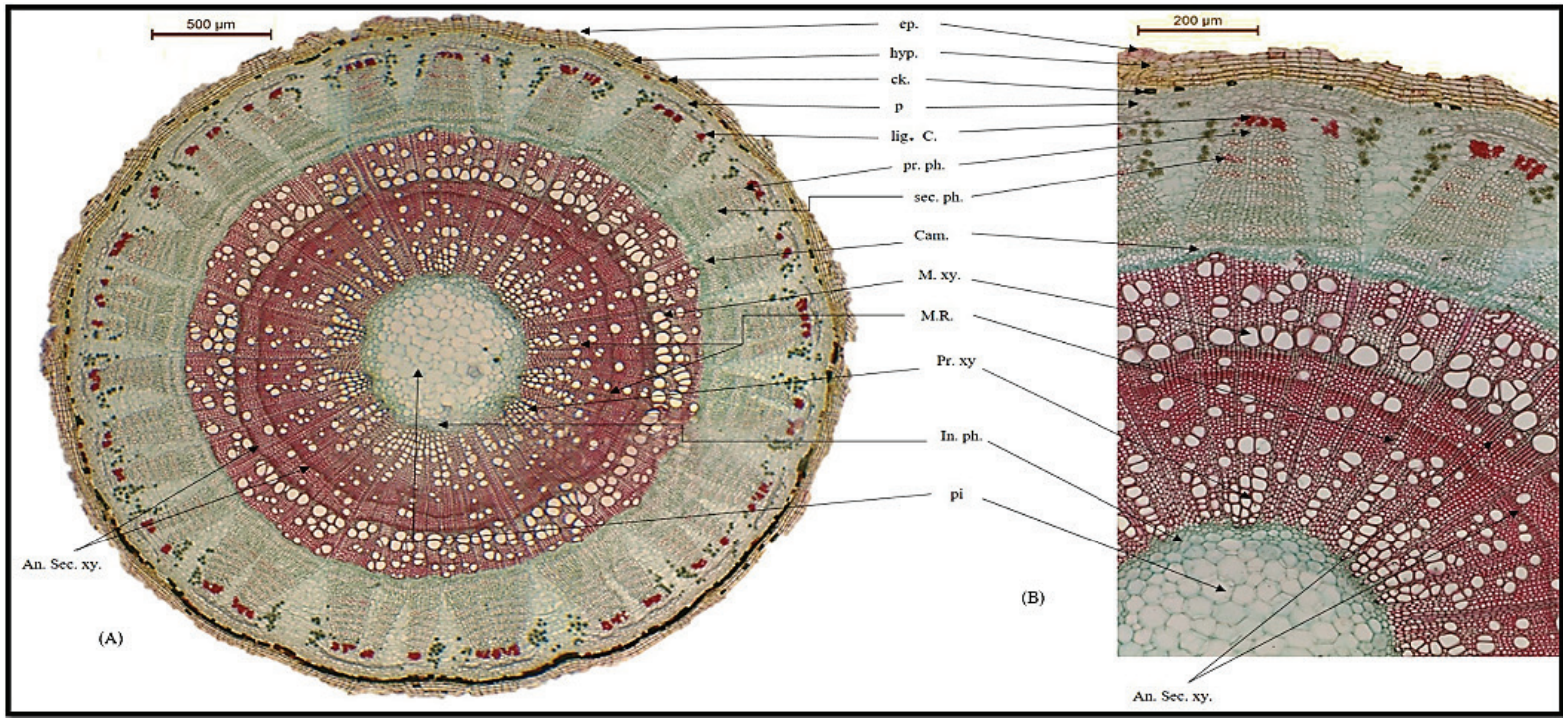

Figure 6. Photographs of the stem. (a) A circular transverse section was taken from the stem of $H$. syriacus L. (Low power) $x=22$. (b) A transverse section was taken from the stem of H. syriacus L. (High power) $x=55$. ep. = epidermis; hyp. = hypodermis; ck. = cork; . = phelloderm; lig.c. = lignified cells; pr. ph. = primary phloem; sec. ph. $=$ secondary phloem; pr. Xy. $=$ protoxylem; M.xy. = Metaxylem; cam. = cambium; An. Sec. xy. $=$ Annual rings of secondary xylem; Med. $\mathrm{R} .=$ medullary rays; In. ph. $=$ intraxylary phloem; pi. $=$ pith.

cortex consisted of four to six rows of parenchyma cells that were elongated and tangential in shape with thin walls. Lignified cells or fibers were tangentially arranged with an inward base forming a triangular shape and red in color. The primary phloem consisted of conducting cells and sieve tubes in addition to a fiber cap. The secondary phloem consisted of sieve tube members, companion cells, scattered parenchyma, and fibers shaped in cluster bands. Protoxylem was formed of tracheids, tracheae with smaller cavities, annular and spiral vessels with thickening towards the center. Metaxylem was formed of pitted thickening vessels directed towards the circumference. Cambium was a single layer of initial cells. Annual rings of secondary xylem were formed of a band of thin simple elements in cylindrical shapes located in the secondary xylem region. Medullary rays consisting of primary parenchyma cells were formed in a ribbon shape and elongated vertically. Intraxylary phloem occurred numerously in small portions, nearly cylindrical in shape surrounding the pith margin, peripherally formed sieve tube elements (in companion cells), and axial and parenchyma ray cells. Pith was present in the center of the transverse section representing a large portion remains of parenchyma cells with profuse intercellular spaces forming a round circular shape center.

\section{Powdered stem}

The powdered stem (Fig. 7) is pale gray in color, odorless, and with a slight bitter mucilaginous taste. Microscopically, 
it is characterized by the presence of:

(a) Hypodermal cells,

(b) Epidermal cells,

(c) Pericyclic fiber,

(d) Fragments of a long wavy fiber with thick walls and a very narrow lumen,

(e) Bundle of narrow walled fibers with the lumen.

The leaf

A transverse section was taken from a leaf of the $H$. syriacus L. which showed the following: (Fig. 8)

A vascular bundle (discrete strands) of tissue was formed of each containing xylem (in upper side) and phloem (in lower side) scattered in a parenchymatic spongy cell bundle format. Each bundle is conjoint, collateral, and closed. The xylem was formed of vessels and tracheids and thin-walled woody parenchyma cells laid in positioned rows towards the upper epidermis. Phloem was formed of sieve tubes, companion cells, and parenchyma phloem cells that were positioned towards the lower epidermis. Crystal clusters were commonly present on the upper surface and formed by crystals of calcium oxalate. Collenchyma cells were parenchymatic cells with thick corners located below the epidermis in patches and directed towards the outer side of the bundle. The upper epidermis was formed of slightly elongated polygonal cells with straight thin walls of cellulose more elongated than the lower epidermis. The lower

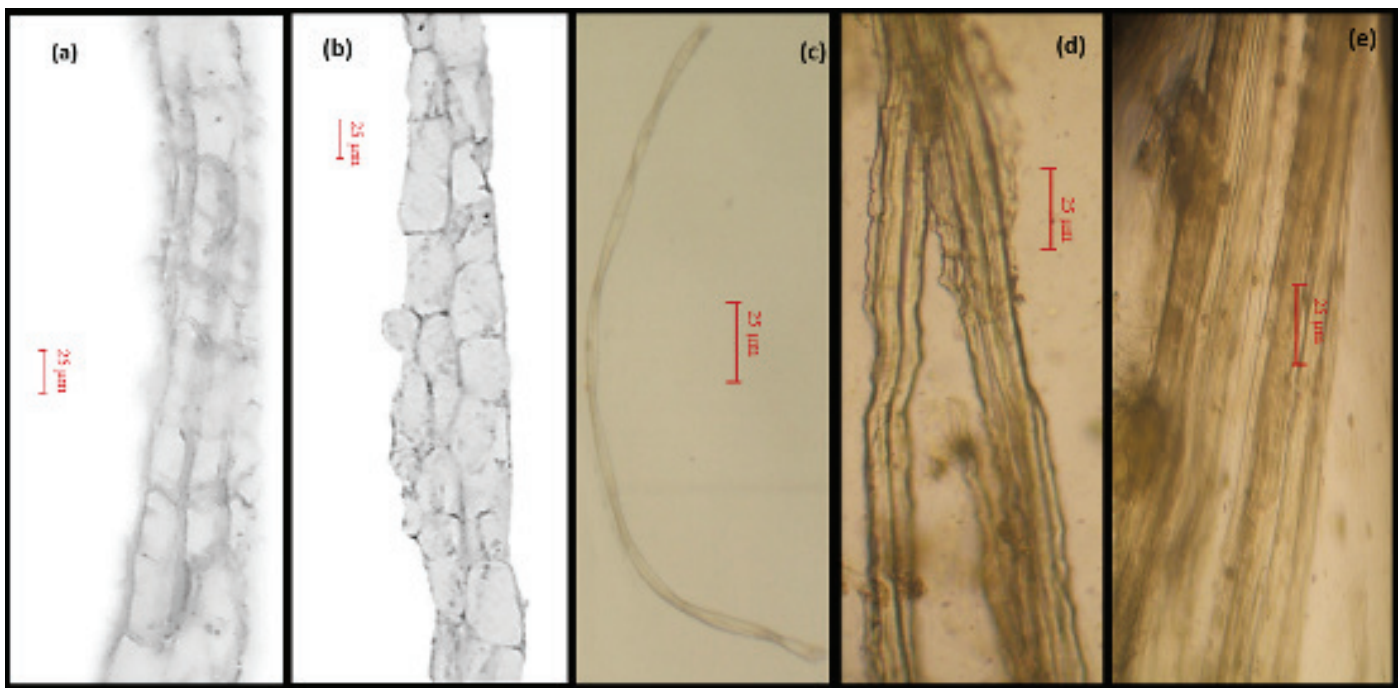

Figure 7. Photographs of powdered stem of $H$. syriacus L. (High power). (a) Hypodermal cells, $X=200$; (b) epidermal cells, $X=160$; (c) pericyclic fiber, $X=320$; (d) fragments of a long wavy fiber with thick walls and very narrow lumen, $X=340$; (e) bundle of fibers narrow walled with lumen, $X=300$.

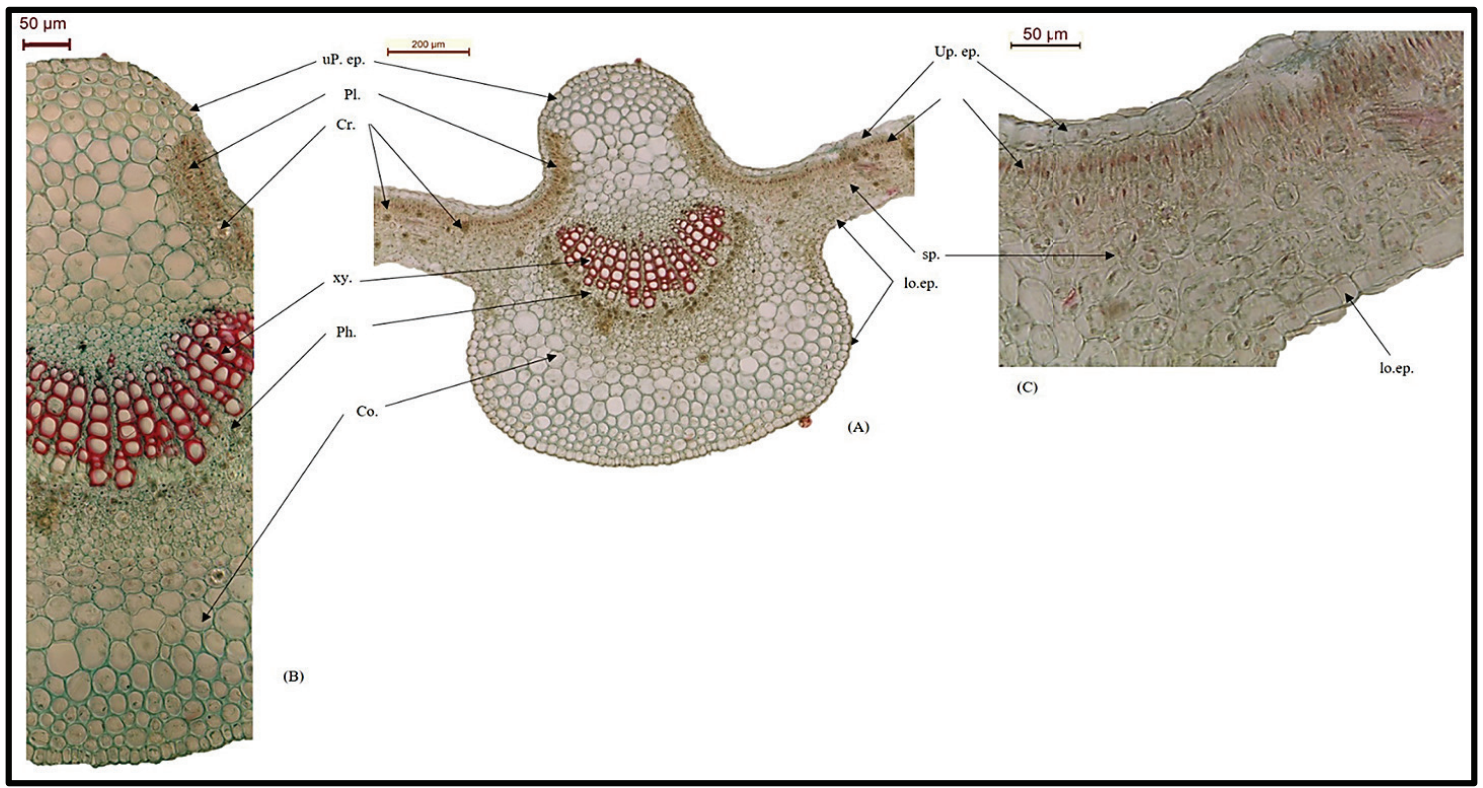

Figure 8. Photographs of transverse sections from leaf of H. syriacus L. (a) Transverse sections from leaf of $H$. syriacus L. (Low power), $X=40$; (b) transverse sections from leaf of H. syriacus L. (High Power), $X=100$; (c) transverse sections from leaf of H. syriacus L. (High Power), $X=140 . X y$. $=x y l e m ;$ ph. $=$ phloem; cr. $=$ calcium oxalate crystal clusters; co. $=$ collenchyma; up.ep. $=$ upper epidermis; lo.ep. $=$ lower epidermis; pl. $=$ palisade cells; sp. $=$ spongy tissues of cells. 
epidermis was formed of slightly wavy polygonal cellulosic thin-walled cells. They were also covered with a smooth cuticle. Palisade cells were cylinder shaped with thin walls containing green plastid. Spongy tissues of cells formed in irregular rows and were rounded in shape. The parenchymatic cells contained cluster crystals (Fig. 8).

\section{The petiole}

A transverse section of the petiole (Fig. 9) with a circular outline was apparent. It showed one layer of elongated epidermal cells, followed by the cortex which was formed of hypoderms with two rows of chlorenchymatous cells. This was followed by parenchyma of six rows enclosed by clusters of calcium oxalate crystal and mucilage cells. The pericycle was present in the form of intermittent separated patches of lignified fibers. The vascular system was formed of six isolated collateral vascular bundles of different sizes arranged in a circular shape and separated by layers of lignified parenchyma. The pith was formed of a wide zone of thin-walled parenchyma enclosed within the vascular system.

\section{Powdered leaf}

The powder of the leaf (Fig. 10) is green in color, characterized by non-aromatic odor and taste. It is microscopically characterized by the following elements:

(a) Paracytic stomata

(b) Non-glandular unicellular hair with basil cells and a round thickened end with epical cell surrounded by calcium-oxalate clusters

(c) Calcium-oxalate crystal clusters

(d) Tracheids

(e) Non-glandular unicellular hair

(f) A calcium-oxalate crystal cluster.

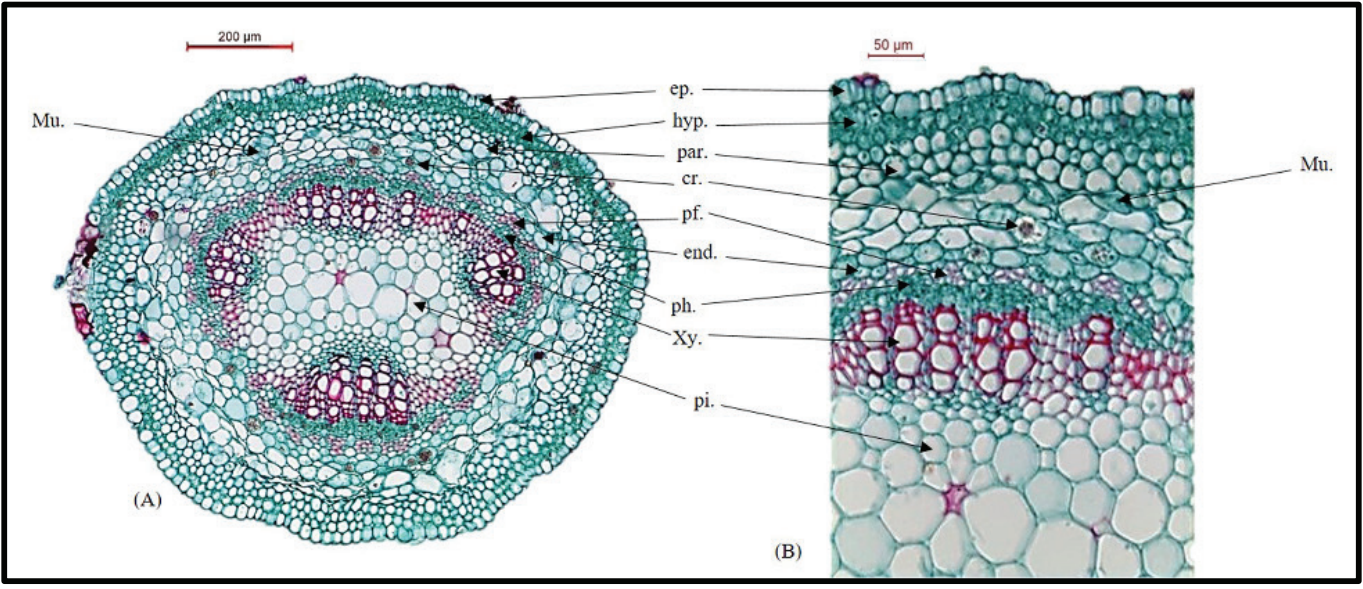

Figure 9. Photographs of transverse section in the leaf petiole of H. syriacus L. (a) Circular transverse section in petiole low power $(x=55)$; (b) transverse section in petiole high power $(x=120)$. ep. $=$ epidermis; hyp. $=$ hypoderms; par. $=$ parenchyma; $c r .=$ crystal clusters of calcium oxalate; mu. $=$ mucilage; pf. $=$ pericyclic fibers; end. $=$ endodermis; ph. $=$ phloem; $x y .=$ xylem; pi. $=$ pith.

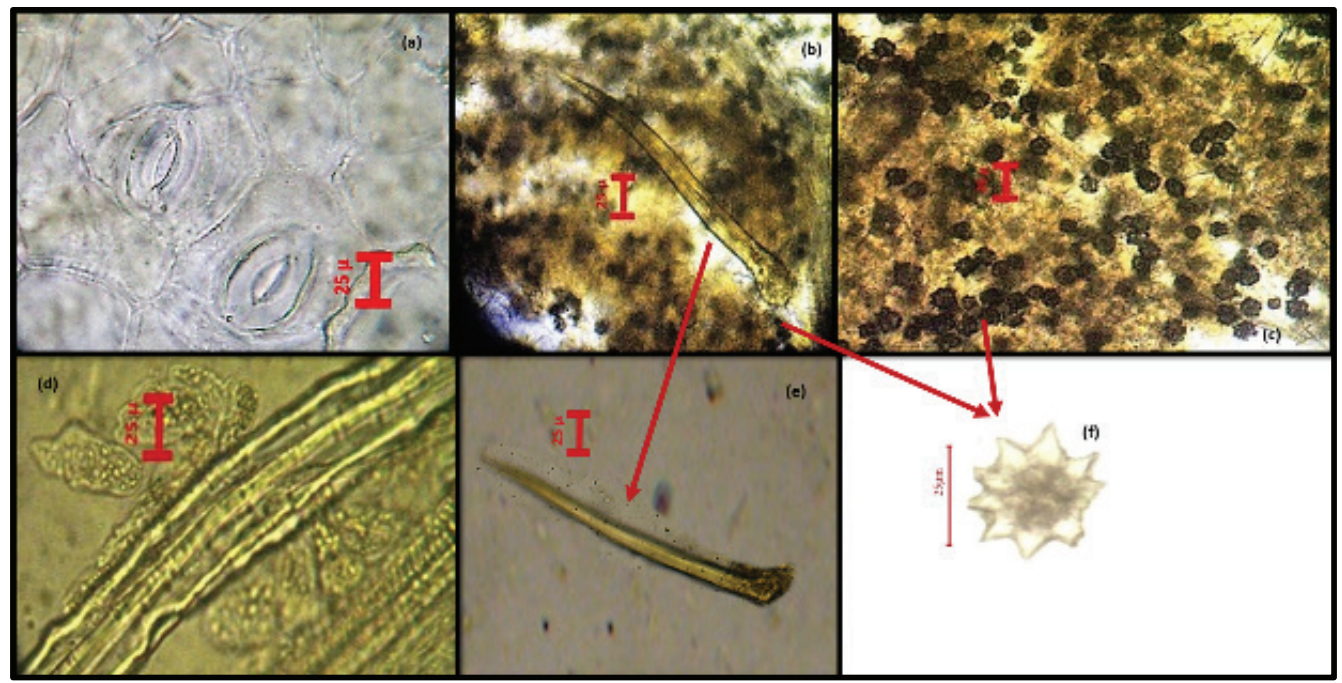

Figure 10. Photographs of powdered leaf of $H$. syriacus L. (High power). (a) Paracytic stomata $X=240$; (b) non-glandular unicellular hair, basil cells round thickened end, epical cell surrounded with calcium-oxalate crystals clusters $X=200$; (c) calcium oxalate crystal clusters $X=160$; (d) Tracheids $X=280$; (e) non-glandular unicellular hair $X=200$; (f) A crystal of calcium-oxalate $X=880$. 


\section{The ovary of the flower}

Transverse and longitudinal sections were taken from an ovary of an $H$. syriacus L. flower which indicated the following: (Figs. 11 and 12)

The ovary was rounded in shape in the section and was formed of five locules, where every locule contained three ovules. The epidermis of the ovary had a single thin layer of outer cells, followed by polygonal elongated parenchymatous cells forming the inner epidermis and containing a mucilaginous cavity. The placenta was a free central placenta located in the middle of the ovary together with five vascular strands forming a star shape. Vascular strands were also located in the middle of the ovary and were formed of xylem vessels.

\section{Powdered flower}

The powdered flower (Fig. 13) is brownish in color, characterized by non-aromatic odor and taste. Microscopically, it was characterized by the presence of elements discussed in the previous sections including;

(a) Cottony hair with basal and apical cells and a long curved thickened wall,

(b) Annular and spiral xylem vessels,

(c) Stellated short branched hair,

(d) Clusters of crystals.

\section{Molecular analysis}

\section{DNA-fingerprint}

Molecular identification of $H$. syriacus L. was carried out using 12 RAPD-PCR primers and was producible. A total of 80 bands were amplified and produced an average of six to seven bands per primer (Fig. 14). The number of RAPD fragments that were amplified ranged from 3 to 10 and the sizes ranged from 426 to 4,812 bp (Table 1). From these 12 primers, primer OPA-20

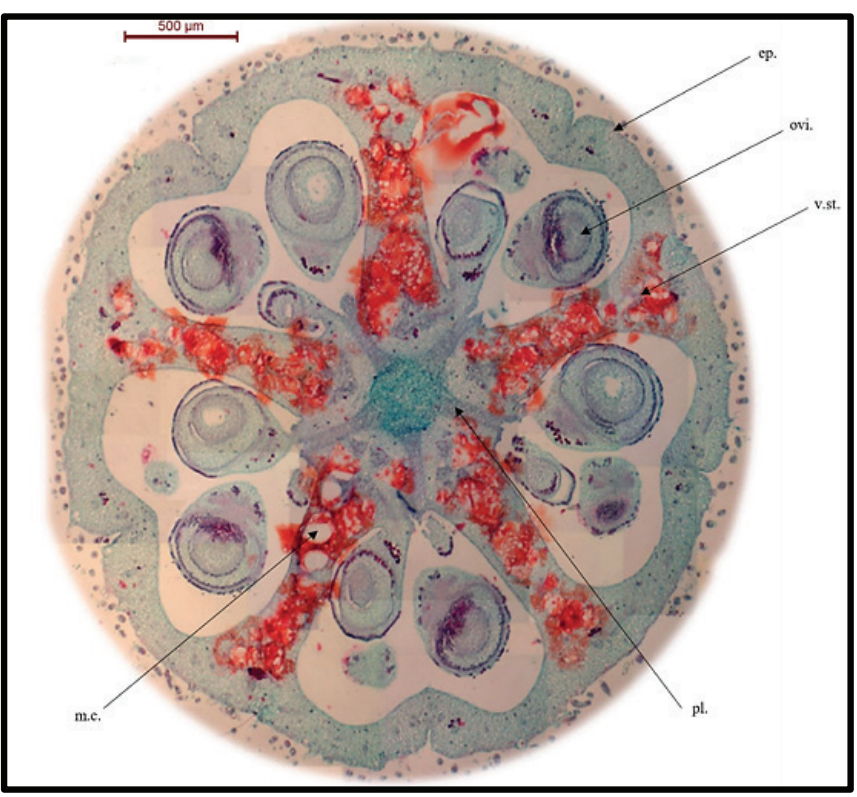

Figure 11. A circular transverse section in the ovary of $H$. syriacus L. (Low power), $X=24$. epi. = epidermis; pl. = placenta; ovi. = ovule; v.st. $=$ vascular strands; mc. $=$ mucilaginous cavity.

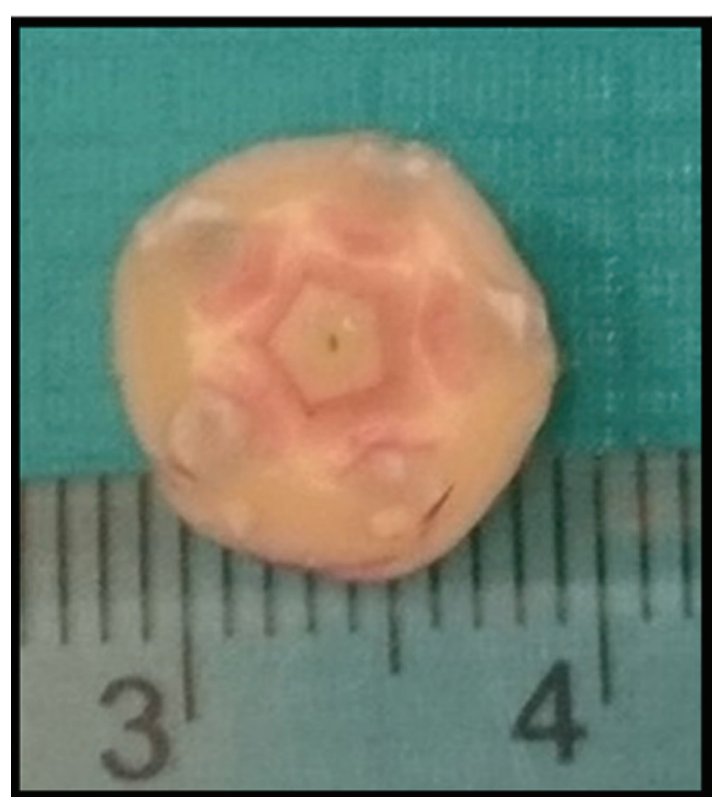

Figure 12. L.S Section in the ovary of H. syriacus L. $X=2$.

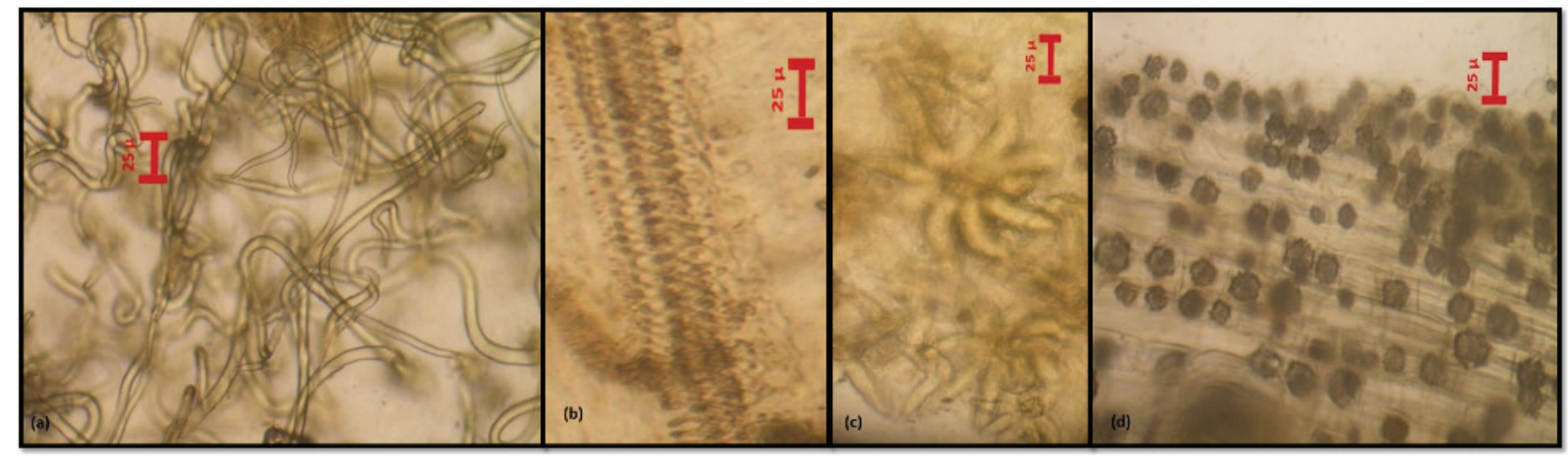

Figure 13. Photographs of powdered flower of $H$. syriacus L. (High power); (a) cottony hair with basal cells and epical cells long curved thickened wall, $X=180$; (b) annular and spiral xylem vessels, $X=240$; (c) stellated short branches hair, $X=280$; (d) Clusters of crystals, $X=160$. 
produced the highest number of fragments and the 10 amplified fragment sizes ranged from about $707-3,754 \mathrm{bp}$. The least band fractions were produced by primer OPB-14 and the three amplified fragment sizes ranged from about 1,522-2,287 bp. The genomic DNA of the plant had induced successive amplifications with different molecular sizes.

\section{Inter-simple sequence repeat}

The ISSR analysis was carried out using 10 primers. Specimens of $H$. syriacus L. was applied and compared to specimens of $H$. sabdariffa $\mathrm{L}$. as a reference, as well as a DNA marker. Out of 10 , only five primers gave satisfactory, clear, and reproducible bands. The ISSR profile revealed the presence of a total of 17 bands. All primers were found to be polymorphic and exhibited $100 \%$ polymorphism. The average of bands per primer was 3.4 as indicated in Table 2. The number of primers produced ranged from 2 (when using HB11 primer) to 5 (when HB 10 and 17899A primers were used). The primer HB10 was producible only with $H$. syriacus L., while primer 17899A was producible only with $H$. sabdariffa L. as shown in Fig. 15. The use of an

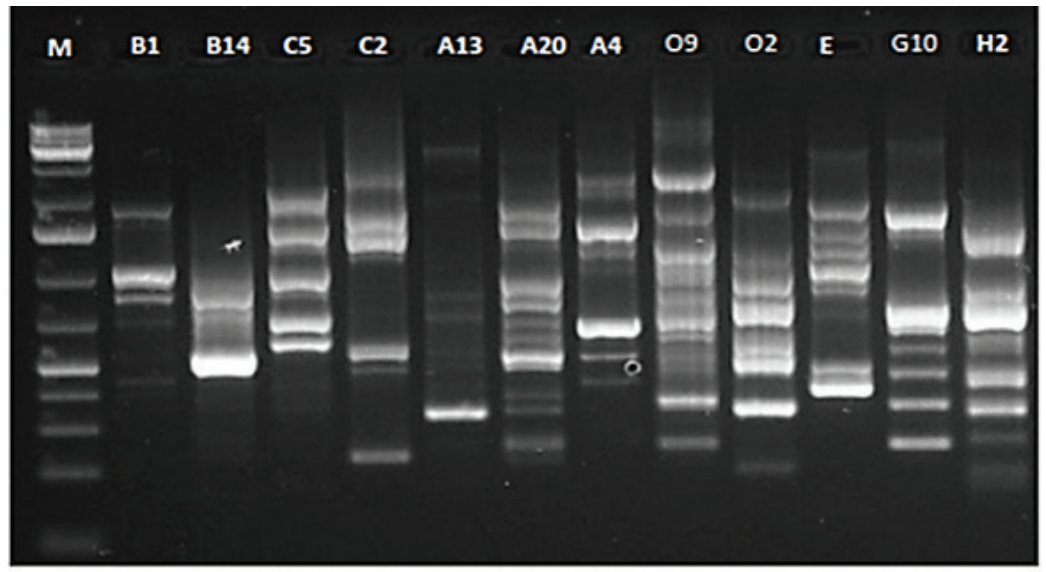

Figure 14. A photograph of RAPD electrophoretic profile of H. syriacus L. generated by the 12 decamer primers (M: DNA marker).

Table 1. RAPD-PCR fragments generated by 12 decamer primers in H. syriacus $\mathrm{L}$.

\begin{tabular}{llcc}
\hline Primers & Primers sequence & Size range of fragments by bp & No. of amplification products \\
\hline OPB-01 & GTTTCGCTCC & $3,901-1,306$ & 5 \\
OPB-14 & TCCGCTCTGG & $2,287-1,522$ & 3 \\
OPC-05 & GATGACCGCC & $4,089-426$ & 7 \\
OPC-02 & GTGAGGCGTC & $4,812-616$ & 6 \\
OPA-13 & CAGCACCCAC & $2,372-893$ & 3 \\
OPA-20 & GTTGCGATCC & $3,754-707$ & 10 \\
OPA-04 & AATCGGGCTG & $4,754-1,306$ & 7 \\
OPO-09 & TCCCACGCAA & $4,736-716$ & 9 \\
OPO-02 & ACGTAGCGTC & $4,218-549$ & 8 \\
OPE-05 & TCAGGGAGGT & $3,852-1,170$ & 7 \\
OPG-10 & AGGGCCGTCT & $4,621-698$ & 7 \\
OPH-02 & TCGGACGTGA & $2,963-539$ & 8 \\
\hline
\end{tabular}

Total $=80 ;$ Mean $=6.67$

Table 2. ISSR-PCR product generated by five primers in $H$. syriacus $\mathrm{L}$. and compared with $H$. sabdariffa $\mathrm{L}$.

\begin{tabular}{lcccc}
\hline Primer & Molecular size (bp) & Number of total bands & $\begin{array}{c}\text { Number of polymorphic } \\
\text { bands }\end{array}$ & Polymorphism (\%) \\
\hline HB11(GT)6CC & $586-1,819$ & 7 & 7 & 100 \\
HB10(GA)6CC & $518-1,819$ & 5 & 5 & 100 \\
HB8(GA)6GG & $238-855$ & 7 & 7 & 100 \\
HB13(GAG)3GC & $556-1,730$ & 6 & 6 & 100 \\
17899A (CA)6AG & $600-1,320$ & 5 & 5 & 100 \\
Total & & 30 & 30 & - \\
Average & & 6 & 6 & 100 \\
\hline
\end{tabular}




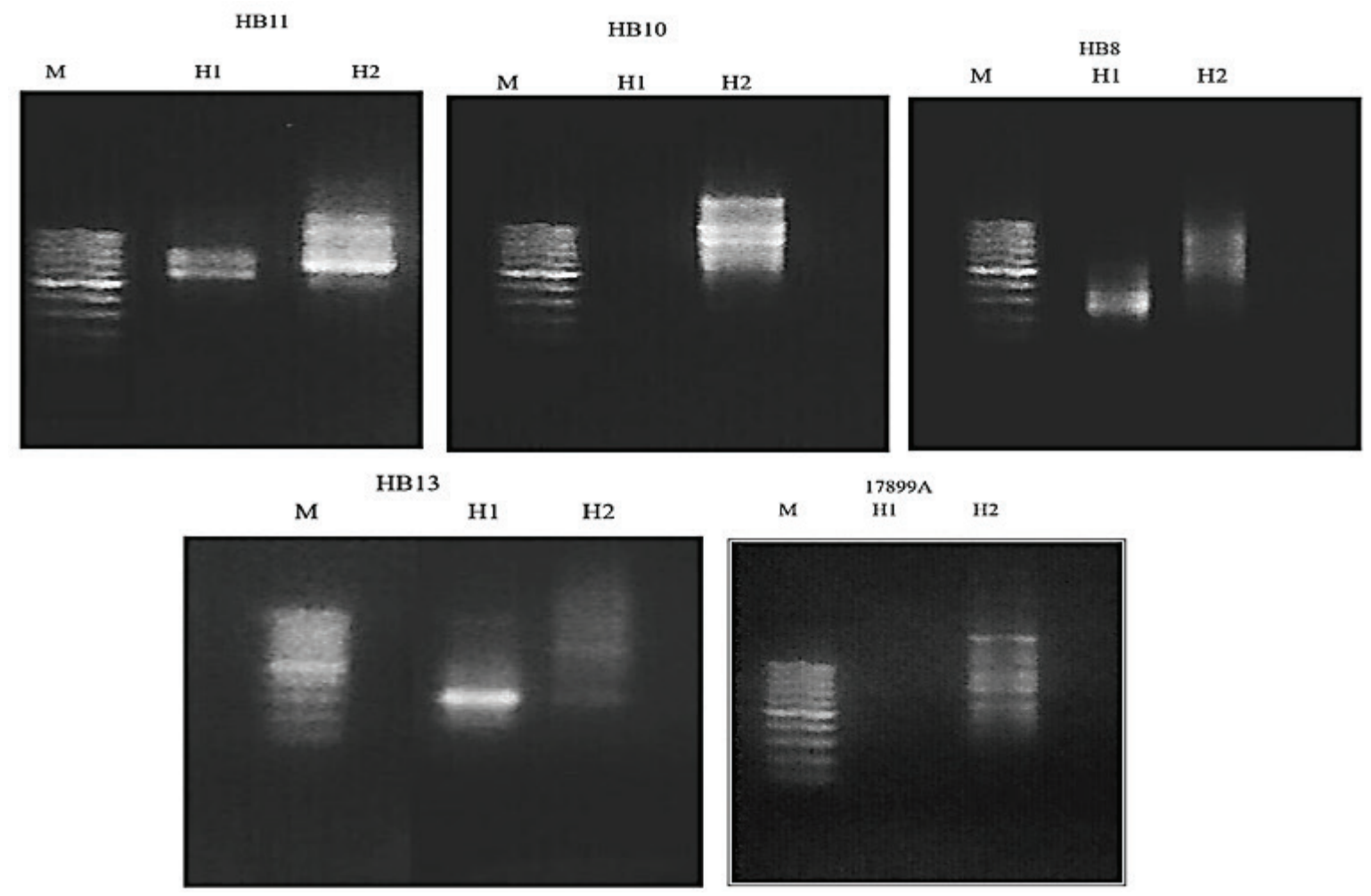

Figure 15. Inter-simple sequence repeats of ISSR H. syriacus L. (H1) and H. sabdariffa L. (H2) using five specific primers.

ISSR profiling technique was successfully used to assess genetic diversity by the amplification of microsatellites that were potential polymorphic regions and to measure levels of relatedness between species and/or groups.

ISSR has proven to be useful in studying the population of plants at the genetic level and noted discrimination between closely related species as previously reported by Gajera et al. (2010) and Kumar et al. (2014).

\section{Protein profile of the flower buds}

The protein profile was carried out using the SDS-PAGE electrophoretic technique on $H$. syriacus $\mathrm{L}$. flowering buds to monitor the active genes expressed in the reproductive organs as shown in Fig. 16. The data analyzed by the gel documentation system revealed the presence of 20 sharp protein bands. The protein bands have a molecular weight ranging from about 250 $25.20 \mathrm{kDa}$ as indicated in Table 3 . The relative mobility $\mathrm{Rf}$ of these bands ranged from 0.05 to 0.97 . The present results revealed the presence of a long sharp chain of polypeptides, as well as low molecular weight proteins (Table 3 )

\section{Determination of protein and amino acid}

The different organs of $H$. syriacus L. contain essential and non-essential amino acids. Results are illustrated in Table 4.

\section{Proximate analysis}

Proximate analyses results were determined by a gravimetric analysis technique $(\mathrm{g} \% \mathrm{~W} / \mathrm{W})$ with reference to the dried material according to A.O.A.C. (2000). Results are illustrated in Table 5.

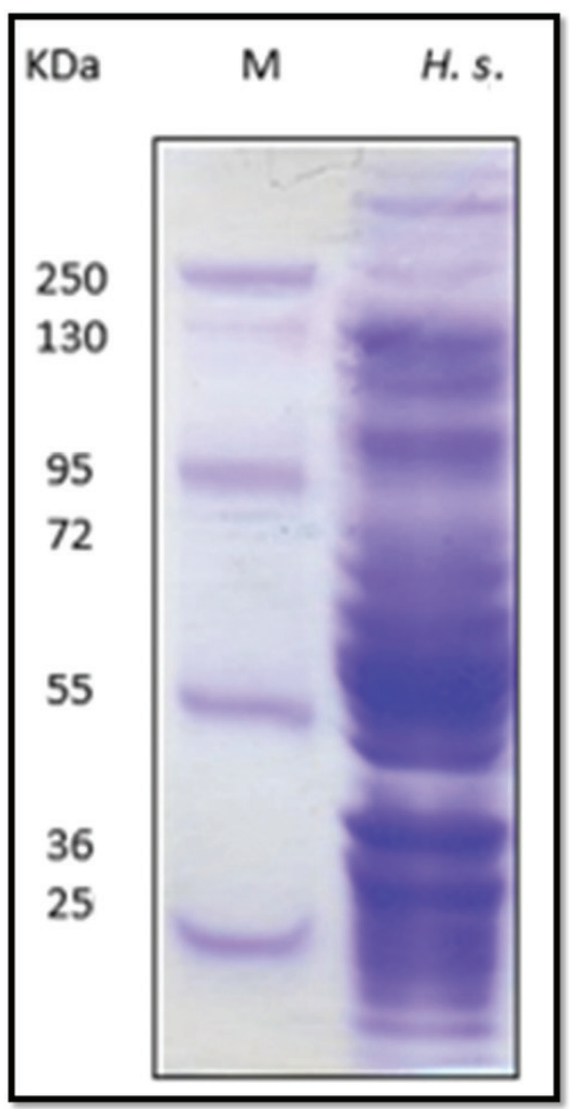

Figure 16. SDS-PAGE electrophoretic profile of $H$. syriacus L. flower buds lane 1, M.: molecular marker with a medium range in $\mathrm{KDa}$; lane 2: $H$. syriacus $\mathrm{L}$. 
Table 3. Protein fingerprint of $H$. syriacus $\mathrm{L}$. flower buds based on molecular weight by K. Dalton and Rf values.

\begin{tabular}{|c|c|c|c|}
\hline Molecular weight (kDa) & Marker & H. syriacus L. & $\mathbf{R}_{\mathrm{f}}$ \\
\hline 250.00 & + & + & 0.05 \\
\hline 130.00 & - & + & 0.09 \\
\hline 97.36 & + & - & 0.12 \\
\hline 95.00 & - & + & 0.13 \\
\hline 73.03 & - & + & 0.19 \\
\hline 72.00 & - & + & 0.20 \\
\hline 66.31 & + & - & 0.25 \\
\hline 58.91 & - & + & 0.32 \\
\hline 55.00 & + & - & 0.36 \\
\hline 48.67 & + & - & 0.43 \\
\hline 44.72 & - & + & 0.45 \\
\hline 40.90 & - & + & 0.47 \\
\hline 36.00 & - & + & 0.52 \\
\hline 35.25 & + & - & 0.60 \\
\hline 33.10 & - & + & 0.66 \\
\hline 30.82 & - & + & 0.73 \\
\hline 29.08 & - & + & 0.81 \\
\hline 28.00 & - & + & 0.87 \\
\hline 26.23 & - & - & 0.93 \\
\hline 25.20 & + & + & 0.97 \\
\hline Total & 7 & 20 & -- \\
\hline
\end{tabular}

Table 4. Results of determination of protein and amino acid content.

\begin{tabular}{|c|c|c|c|c|}
\hline \multirow{2}{*}{\multicolumn{2}{|c|}{ Protein and amino acid contents }} & \multicolumn{3}{|c|}{ H. syriacus $\mathrm{L}$. } \\
\hline & & Flowers & Leaves & Stem \\
\hline \multicolumn{2}{|c|}{ Protein content $(\%)$} & 10.60 & 20.20 & 7.60 \\
\hline \multirow{7}{*}{$\begin{array}{l}\text { Essential amino } \\
\text { acids ( } \% \text { g on dry } \\
\text { weight) }\end{array}$} & Histidine & 0.21 & 0.39 & 0.12 \\
\hline & Isoleucine & 0.29 & 0.60 & 0.16 \\
\hline & Leucine & 0.47 & 1.10 & 0.26 \\
\hline & Lysine & 0.36 & 0.72 & 0.22 \\
\hline & Methionine & 0.09 & 0.19 & 0.04 \\
\hline & Phenyl alanine & 0.31 & 0.81 & 0.19 \\
\hline & Threonine & 0.32 & 0.72 & 0.16 \\
\hline \multirow{10}{*}{$\begin{array}{c}\text { Non-essential amino } \\
\text { acids (\% g on dry } \\
\text { weight) }\end{array}$} & Valine & 0.38 & 0.80 & 0.21 \\
\hline & Alanine & 0.25 & 0.49 & 0.13 \\
\hline & Arginine & 0.36 & 0.81 & 0.39 \\
\hline & Aspartic acid & 0.81 & 1.94 & 0.91 \\
\hline & Cysteine & 0.17 & 0.24 & 0.07 \\
\hline & Glutamic acid & 0.95 & 1.45 & 0.44 \\
\hline & Glycine & 0.35 & 0.69 & 0.19 \\
\hline & Proline & 0.44 & 1.26 & 0.48 \\
\hline & Serine & 0.32 & 0.63 & 0.17 \\
\hline & Tyrosine & 0.25 & 0.54 & 0.17 \\
\hline
\end{tabular}


Table 5. Proximate analysis of leaves, stems, and flowers of $H$. syriacus $\mathrm{L}$.

\begin{tabular}{clccc}
\hline & & \multicolumn{3}{c}{ H. syriacus $\mathbf{L}}$. \\
\cline { 3 - 5 } & & Flowers & Leaves & Stems \\
\hline & Moisture & 10.13 & 9.70 & 8.50 \\
& Total ash & 17.40 & 16.70 & 7.50 \\
& Acid insoluble ash & 2.79 & 0.225 & 0.02 \\
& Water soluble ash & 5.86 & 8.60 & 4.06 \\
& Fiber Content & 11.97 & 11.64 & 36.98 \\
\hline
\end{tabular}

\section{CONCLUSION}

Hibiscus syriacus L. is a shrub belonging to the Malvaceae family called Rose of Sharon with effectively proven biological functions, such as a fungicide, antipyretic, anthelmintic, hypoglycemic, anti-microbacterial, antioxidant, and significant cytotoxic activities. It is characterized morphologically as its flower consists of five petals (purple to blue lavender chiffon in color) with a crimson base. Microscopically, its stem is devoid of stomata. Its leaves and ovaries contain calcium oxalate crystal clusters, made up of five locules, in which every locule contains three ovules. It can be concluded that the analysis of the amplified fragments (generated by RAPD reactions) revealed that the genetic profile of $H$. syriacus L. produced diverse molecular patterns. The primers OPA-20 and OPB-14 can be used for the identification of this species since they generate producible fragments with a wide range of molecular sizes.

The high percentage of polymorphism revealed after using ISSR markers, indicated the presence of genetic variability among the studied species $H$. syriacus $L$. and the reference plant used $H$. sabdariffa L., indicating the presence of variability in morphological characteristics and biological activities.

The protein profile of the flower buds was analyzed as one more genetic character, using SDS-gel electrophoresis, can reflect the transcriptional events during the development of the plant. A protein profile can be used for the identification and the differentiation between species.

The highest percentage of protein content $(20.20 \%)$ is in the leaves of H. syriacus L., followed by the flowers (10.60\%), then stem $(7.60 \%)$, where they show small variations from the flowers. Essential and non-essential amino acid contents were predominant in the leaves. The flowers showed higher percentages than the stems. The essential amino acid Leucine and non-essential amino acid Aspartic acid was found in a higher percentage in the leaves, than that of the flowers and stem.

\section{REFERENCES}

AOAC. Official methods of analysis chemists international. 17th edition, Gaitherburg, MD, 2000.

Block RJ, Durrum EL, Zweig G. A manual of paper chromatography and paper electrophoresis. 2nd edition, Academic Press, New York, NY, 1958.

Christenhusz M, Byng J. The number of known plants species in the world and its annual increase. Phytotaxa, 2016; 261(3):201-17.

Gajera B, Kumar N, Singh A, Punvar B, Ravikiran R, Subhash N, Jadeja G. Assessment of genetic diversity in castor (Ricinus communis L.) using RAPD and ISSR markers. Ind Crop Prod, 2010; 32:491-8.

Gallagher S. One dimensional gel electrophoresis of proteins. Curr Protoc Protein Sci, 2012; 68(1):10.1.1-44.
Gautam R, Saklani A, Jachak S. Review Indian medicinal plants as a source of antimycobacterial agents. J Ethnopharmacol, 2007; 110:200-34.

Huxley A, Griffiths M, Levy M. The new royal horticultural society dictionary of gardening. Vol. 2. Macmillan Press, Great Britain, UK, 1992

Ince AG, Karaca M, Onus AN. Genetic relationships within and between Capsicum species. Biochem Genet, 2010; 48:83-95.

Kraus JE, Arduin M. Basic manual methods in plant morphology. Basic manual methods in plant morphology. Edur Rio de Janeiro, 1997.

Kumar A, Mishra P, Singh S, Sundaresan V. Efficiency of ISSR and RAPD markers in genetic divergence analysis and conservation management of Justicia adhatoda L., a medicinal plant. Plant Syst Evol, 2014; 300:1409-20.

Laemmli UK. Cleavage of structural proteins during the assembly of the head of bacteriophage T4. Nature, 1970; 227:680-5.

Maganha EG, Halmenschlager RC, Rosa RM, Henriques JAP, Ramos Ap, Saffi J. Pharmacological evidences for the extracts and secondry metabolites from plants of the genus Hibiscus. Food Chem, 2010; 118(1):1-10.

Metcalfe C, Chalk L. Anatomy of the dicotyledons. Vol. 1. Clarendon Press, Oxford; Great Britin, UK, 1950.

Perez GR, Zavala SM, Perez GC. Review, Antidiabetic effect of compounds isolated from plants. Phytomedicine, 1998; 5(1):55-75.

Reddy MP, Sarla N, Siddiq EA. Inter simple sequence repeat (ISSR) polymorphism and its application in plant breeding. Euphytica, 2002; 128:9-17.

Sundaram S, Purwar S. Assessment of genetic diversity among fenugreek (Trigonella foenum-graecum L.). J Med Plant Res, 2011; 5(9):1543-8.

Tripathi N, Chouhan DS, Saini N, Tiwari S. Assessment of genetic variations among highly endangered medicinal plant Bacopa monnieri (L.) from Central India using RAPD and ISSR analysis. 3 Biotech, 2012; 2(4):327-36.

Welsh S. Utah Flora: Malvaceae. Great Basin Naturalist, 1980; 40(1):27-37.

Wilson VL, Jones PA. DNA methylation decreases in aging but not in immortal cells. Science, 1983; 220:1055-7.

Yun BS, Lee IK, Ryoo IJ, Yoo ID. Coumarins with monoamine oxidase inhibitory activity and antioxidative coumarino-lignans from Hibiscus syriacus. J Nat Prod, 2001; 64(9):1238-40.

Zietkiewicz E, Rafalski A, Labuda D. Genome fingerprinting by simple sequence repeat (SSR)-anchored polymerase chain reaction amplification. Genomics, 1994; 20:176-18.

How to cite this article:

El Shazly J, El Gayed SH, Kandil ZA, Yassin NA, Tawab SA, ElAlfy TSM. Botanical and genetic characterization of Hibiscus syriacus L. cultivated in Egypt. J Appl Pharm Sci, 2018; 8(12): 092-103. 